\title{
Phytoplankton, protozooplankton and nutrient dynamics in the Bornholm Basin (Baltic Sea) in 2002-2003 during the German GLOBEC Project
}

\author{
Justus E. E. van Beusekom · Dirk Mengedoht · \\ Christina B. Augustin · Mario Schilling • \\ Maarten Boersma
}

Received: 26 March 2006/Accepted: 16 March 2007 / Published online: 18 August 2007

(C) Springer-Verlag 2007

\begin{abstract}
From March 2002 to until April 2003 we investigated the seasonal nutrient and phytoplankton dynamics in the central Bornholm Basin (Baltic Sea) within the framework of the German GLOBEC Project. We choose a nested approach consisting of vertical fluorescence profiles, phytoplankton counts and nutrient analyses. The Fluoroprobe (MultiProbe, BBE Moldaenke) is capable of distinguishing four algal groups (Cryptophyceae, Cyanophyceae, Chlorophyceae, Bacillariophyceae + Dinophyceae). Winter nutrient concentrations were about $5 \mu \mathrm{M} \mathrm{NO}{ }_{3}$ and $0.5 \mu \mathrm{M} \mathrm{PO}_{4}$ in the central Basin. The spring phytoplankton bloom was dominated by the diatom Skeletonema sp. and reached a maximum of about $270 \mu \mathrm{g}$ $\mathrm{C} / \mathrm{l}$ before the onset of the seasonal stratification. Protozooplankton was dominated by the Mesodinium rubrum ( a phototrophic ciliate $=$ Myrionecta rubra $)$ and reached a
\end{abstract}

J. E. E. van Beusekom ( $₫)$

Wadden Sea Station Sylt. Alfred-Wegener-Institute for Polar and Marine Research, Hafenstrasse 43,

List/Sylt 25992, Germany

e-mail: Justus.van.Beusekom@awi.de

D. Mengedoht

Alfred-Wegener-Institute for Polar and Marine Research,

P.O.Box 12 0161, 27515 Bremerhaven, Germany

\section{B. Augustin - M. Boersma}

Biologische Anstalt Helgoland,

Alfred-Wegener-Institute for Polar and Marine Research, P.O.Box 180, 27483 Helgoland, Germany

\section{Schilling}

Leibniz-Institut für Ostseeforschung Warnemünde,

Seestrasse 15, 18119 Rostock, Germany

M. Boersma

Institute for Coastal Research, GKSS-Research Centre,

Max-Planck-Straße 1, 21502 Geesthacht, Germany maximum biomass of about 200-300 $\mu \mathrm{g} \mathrm{C/1}$ about 2 weeks after the demise of the diatom spring bloom. During summer, the water column was stratified and a subsurface maximum developed near the thermocline consisting of Bacillariophyceae, Cryptophycea and other phototrophic flagellates. Phytoplankton and protozooplankton biomass was generally low. Nutrient concentrations point towards a nitrogen limitation during this period. The stratification period ended during September and surface nutrient concentrations increased again. Protozooplankton reached a second maximum during September. With the Fluoroprobe small scale structures in the plankton community could be detected like a subsurface Cryptophyceae maximum near the thermocline that however, could not be confirmed by cell counts. The chlorophyll a estimate of the Fluoroprobe was in good agreement with the phytoplankton biomass estimated from counts. We conclude that only by combining modern sensing technology with microscopy, the small-scale dynamics and taxonomic spectrum of the plankton can be fully captured.

Keywords Phytoplankton · Nutrients - Fluorescence · Fluoroprobe · Baltic · GLOBEC

\section{Introduction}

Satellite observation technology has greatly furthered our knowledge on phytoplankton dynamics and water quality (e.g. Platt and Sathyendranath 1988), especially on larger scales. However, many aspects of seasonal succession and distributions of algae remain elusive. This is caused on the one hand by the fact that remote sensing technology detects radiation, which originates within the surface layer. This penetration depth is usually less than $25 \%$ of total euphotic 
zone (Gordon and McCluney 1975). Consequently the information obtained by means of remote sensing does not represent the pigment concentration within the euphotic layer but within the penetration depth. If the vertical distribution of chlorophyll within the euphotic layer is homogeneous then the satellite estimation itself provides useful information for primary production studies, but this is seldom the case. On the other hand remote sensing technology by its nature (looking at pigments) will never yield the taxonomic resolution needed for some studies.

The GLOBEC-Germany (Global Ocean Ecosystem Dynamics) project (Alheit 2004) is such a project where the resolution of satellite imaging techniques does not suffice. One of the key issues of the GLOBEC-project is to further our knowledge on the coupling between copepod and fish larvae dynamics. Copepod production and population dynamics is highly dependent on the dynamics of their food (Hirche et al. 1997; Augustin and Boersma 2006; Peters et al. 2006). The condition of larval fish can be influenced by the phytoplankton community (St. John et al. 2001) or even by the nutritional status of phytoplankton species (Malzahn 2006). Therefore it is of vital importance to have a proper knowledge of the dynamics of phytoplankton. Even though these dynamics in the Baltic have been studied in great detail before, both experimentally (Kivi 1993; Wasmund et al. 1998; Fleming and Kaitala 2006) as well as in modelling exercises (Fennel 1995) most of these studies focused almost exclusively on one depth stratum, or were integrated over depth. We do, however, know that copepod distributions in the Baltic have a significant vertical structure, with in many cases sub-surface maxima (Peters et al. 2006, Renz and Hirche 2006) and hence looking at integrated samples will cause a substantial amount of detail to be lost. Unfortunately, the effort involved in samplings that have a high resolution both in time and in space (both vertically and horizontally), is too high for most institutions. The GLOBEC-Germany project made such a sampling effort possible, as many different institutions were involved. To reach a balance between the limited resources allocated for phytoplankton studies and the large number of stations visited we combined classical microscopic observations with an in situ automatic measuring device, a fluorescence probe attached to the CTD system, able to differentiate between different algal classes throughout the water column (Beutler et al. 2001, 2002).

It has become increasingly clear that not only phytoplankton is of importance as food for copepods, but that many copepod species that were previously regarded as herbivorous actually consume considerable amounts of heterotrophic protozoans such as ciliates (Graneli and Turner 2002; Maar et al. 2004). To date little is known on the seasonal dynamics of heterotrophs in the plankton in the Baltic (Setala and Kivi 2003; Johansson et al. 2004), and detailed information on their vertical distribution is difficult to find (but see Maar et al. 2002; Setala and Kivi 2003). Finally, our newest results show that the nutritional status of food (mineral limitations of the algae) not only influence the copepods feeding on them as reflected by changed egg production rates (Augustin and Boersma 2006). Also the larval fish feeding on these differently fed copepods have different nutritional conditions (Malzahn 2006), which could have severe consequences for recruitment, and the functioning of the whole ecosystem. Hence, in this study we set out (1) to describe the seasonal phytoplankton dynamics, explicitly investigating the depth distributions; (2) to investigate the seasonal dynamics of protozooplankton, as these are often an important food source for copepods; and (3) to describe the seasonal dynamics of the most important macronutrients. In this study, we focus on the seasonal dynamics at Station 23 in the central Bornholm Basin, as this area was the primary research location of the GLOBEC-Germany project, and it is the area most important in our understanding the seasonal dynamics and recruitment of commercially interesting fish (Hinrichsen et al. 2003).

\section{Methods}

The sampling for phytoplankton, protozooplankton and nutrients was conducted during 11 cruises, from March 2002 to until April 2003 on a station grid in the Bornholm Basin, Baltic Sea. In this study, we will concentrate on the main focus station of these cruises only, Station 23, which is in the central part of the Bornholm Basin $\left(55^{\circ} 17.5^{\prime} \mathrm{N}\right.$ $\left.15^{\circ} 45^{\prime} \mathrm{E}\right)$. This station is about five nautical miles northwest of the Helcom Monitoring station 213 (K2). The vertical phytoplankton distribution was measured using a Fluoroprobe (bbe Moldaenke, Kronshagen, Germany). This probe can distinguish between Chlorophyceae, Cyanophyceae, Cryptophyceae and Bacillariophyceae + Dinophyceae on the basis of their fluorescence characteristics (Beutler et al. 2001, 2002). The instrument is based on the measurement of chlorophyll fluorescence emission after being excited at five different wavelengths. In the instrument five light-emitting diodes (LEDs) are switched on sequentially at a frequency of $5 \mathrm{kHz}$. The measuring pulse duration is $0.1 \mathrm{~ms}$. Fluorescence emission of PS II around $685 \mathrm{~nm}$ is measured by a photomultiplier. Based on stored fluorescence spectra of the different algal groups, the relative contribution of each algal group is calculated. After calibration, a very good correlation of the measured fluorescence with extracted chlorophyll is found (Beutler et al. 2002). The probe was calibrated by the company with phytoplankton cultures. No independent checks were made during the cruises. 
For the phytoplankton and protozooplankton samples we took discrete water samples from 5 to 10 depth levels, depending on the stratification patterns, such that at least two samples were taken from above the thermocline, one from mid-water, and two around and in the halocline. Plankton samples were fixed with acidified Lugol's solution and usually $25-50 \mathrm{ml}$ of sample were counted with an inverted microscope after Utermöhl (1958). Phytoplankton as well as protozooplankton cell size was converted to biomass according to Edler (1979) and Putt and Stoecker (1989). If possible, identification was up to species level. Nutrient samples were taken from the same discrete water sample as the phytoplankton samples. Water samples were filtered on board with in-line filters $(0.4 \mu \mathrm{m}$ pore width) mounted on $50 \mathrm{ml}$ syringes, filled in $10 \mathrm{ml}$ vials, stored at -20 to $-40^{\circ} \mathrm{C}$ and analysed in the laboratory with standard AutoAnalyser techniques (Bran and Luebbe AA3) about 49 months after sampling.

\section{Results}

During March and April 2002, deep mixing down to $60 \mathrm{~m}$ prevailed at Station 23. Water temperature in the upper layer was around $4-5^{\circ} \mathrm{C}$ (Fig. 1). From mid-May onward, a rapid temperature increase was observed and during May a thermocline developed that lasted until October. The thermocline was located between 20 and $30 \mathrm{~m}$. Highest temperatures of about $20^{\circ} \mathrm{C}$ and the shallowest thermocline at 16-20 m were observed during the end of August. From then onward, the surface water cooled to reach minimum temperatures during February 2003.

Phytoplankton standing stock started to increase before the stratification had developed and densities reached a maximum in April with a fluorescence signal corresponding to about $5 \mu \mathrm{g}$ chlorophyll $a 1^{-1}$ (Fig. 2). During the stratification period, the phytoplankton was restricted to the upper mixed water layer. During August and September we observed a deep-layer chlorophyll maximum near the thermocline. After September, the upper mixed layer gradually deepened and phytoplankton standing stock decreased to values below a fluorescence signal of $0.25 \mu \mathrm{g}$ chlorophyll $a 1^{-1}$ during winter 2002-2003. According to the Fluoroprobe readings diatoms and autotrophic dinoflagellates dominated the phytoplankton through most of the year (compare the upper panels of Fig. 2). In addition, Cryptophyceae (Fig. 2, bottom panel) were clearly present in the chlorophyll maximum during August and September. From May to October the Fluoroprobe readings suggested the presence of Cyanophyceae near the surface (data not shown).

Results from the plankton counts confirm the general pattern revealed by the Fluoroprobe with maximum biomass during spring and a small secondary bloom during summer. Especially during spring diatoms dominated the phytoplankton (Fig. 3a). Skeletonema sp. was the most important species with a maximum biomass of about $270 \mu \mathrm{g} \mathrm{C}^{-1}$. After the Skeletonema bloom, the dinoflagellate Peridiniella catenata and athecate dinoflagellates gradually gained dominance, reaching maximum values of 50-100 $\mu \mathrm{g} \mathrm{C}^{-1}$ during the end of April. During summer, the biomass of diatoms and dinoflagellates was mostly below $10 \mu \mathrm{g} \mathrm{C}^{-1}$. Nanoflagellates and Cyanophyceae like Aphanizomenon or Microcystis were dominant albeit with biomasses mostly below $50 \mu \mathrm{g} \mathrm{C}^{-1}$ (Table 1). The dominant phytoplankton and protozooplankton species in the upper $10 \mathrm{~m}$ are summarized in Table 1.

Protozooplankton biomass closely followed the spring bloom (Fig. 3b) increasing from about $50 \mu \mathrm{g} \mathrm{C}^{-1}$ (early April) to values between 200 and $300 \mu \mathrm{g} \mathrm{C} 1^{-1}$ during the end of April. The maximum was reached about 2 weeks after the diatom spring bloom. During spring and early
Fig. 1 Vertical distribution of temperature at Station 23 in the central Bornholm Basin from March 2002 to until May 2003. Vertical lines indicate cruises; between cruises the data were interpolated

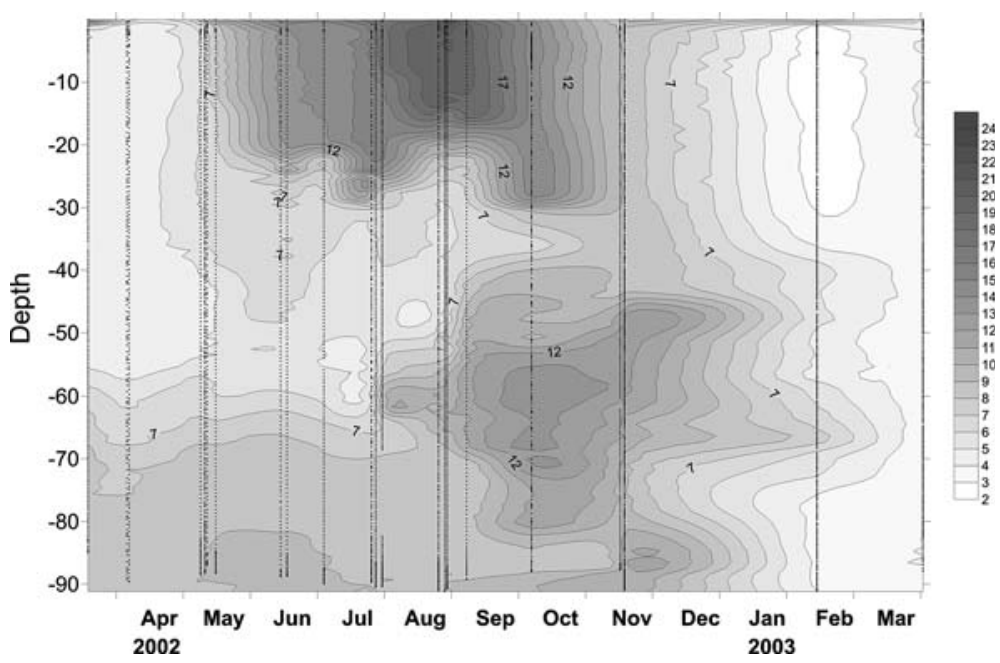



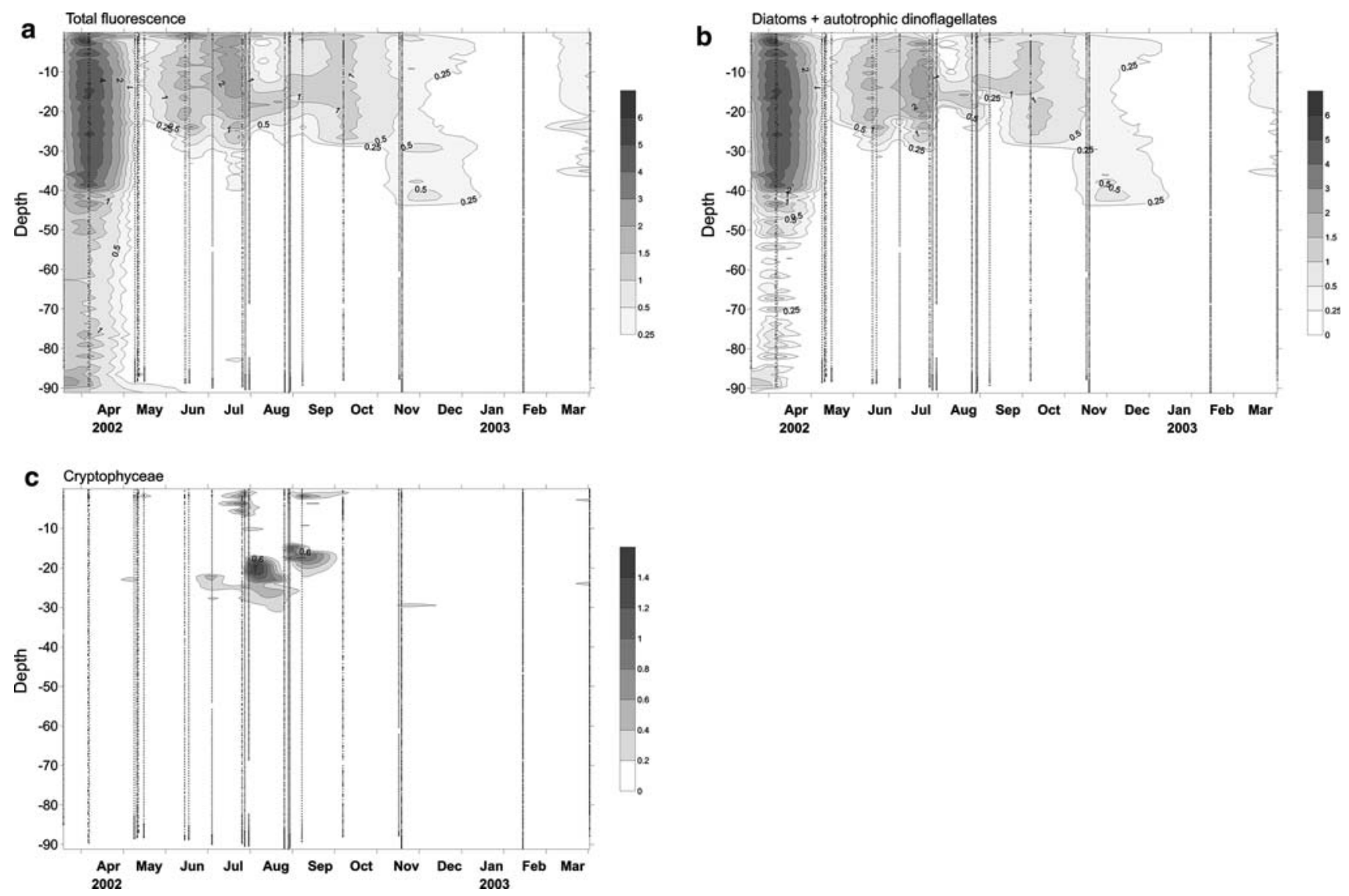

Fig. 2 Seasonal dynamics of total fluorescence (rel. units $\sim$ microgram chlorophyll $1^{-1}$ ) (upper panel), fluorescence attributed to diatoms and autotrophic dinoflagellates (middle panel), and fluorescence attributed to cryptophyceae (lower panel) in the Bornholm Basin

summer, Mesodinium rubrum dominated the protozooplankton whereas during late summer Helicostomella subulata and Strombilidium spp. gained importance with biomass up to $130 \mu \mathrm{g} \mathrm{C}^{-1}$. The dominant protozooplankton species in the upper $10 \mathrm{~m}$ are summarized in Table 1.

Figure 4 gives an overview of the seasonal dynamics of mean diatom, dinoflagellate and protozooplankton biomass in the upper $10 \mathrm{~m}$ from March to November. The diatom bloom (mainly Skeletonema sp.) peaked during early April and was followed by a dinoflagellate bloom. The latter bloom coincided with a protozooplankton bloom dominated by Mesodinium rubrum. During summer biomass was generally low. During late summer a second protozooplankton bloom developed this time not dominated by Mesodinium but by Helicostomella subulata.

The total biomass estimated from the enumerated phytoplankton samples correlates well with the chlorophyll levels estimated by the Fluoroprobe (Fig. 5). The average carbon/chlorophyll $a$ ratio (the latter based on the fluorescence reading) of about 50 is within a reasonable range (e.g., Cloern et al. 1995).
Figure 6 compares the total fluorescence reading attributed by the Fluoroprobe to the entire plankton community with the fluorescence attributed to diatoms plus autotrophic dinoflagellates for the enumerated samples. The good correlation and the slope of almost one suggest that the latter groups (diatoms, dinoflagellates) dominate the phytoplankton at all times. This is correct for the spring bloom. However, especially during low biomass phases as observed during summer, the enumerated phytoplankton samples show that other groups like Cyanophyceae or nanoflagellates may dominate over diatoms and dinoflagellates (Table 1). It should be noted that the major protozoan Mesodinium rubrum is capable of photosynthesis (e.g., Gustafson et al. 2000) and the large biomass may be interpreted as the presence of freeliving algae. We checked whether including Mesodinium biomass would improve the relation between fluorescence and autotrophic biomass and total fluorescence with a multiple regression analysis. We found no significant correlation between the residuals of the regression shown in Fig. 6 and Mesodinium biomass. However, unfortunately due to technical problems no Fluoroprobe readings 
Fig. 3 Seasonal dynamics of diatom biomass (based on counts, units in $\mu \mathrm{g} \mathrm{C} 1^{-1}$, upper panel) and protozoans (lower panel) in the upper $70 \mathrm{~m}$ of the Bornholm Basin. In April 2002 one extreme value of $518 \mu \mathrm{g} \mathrm{C}^{-1}$ was observed in $30 \mathrm{~m}$ depth
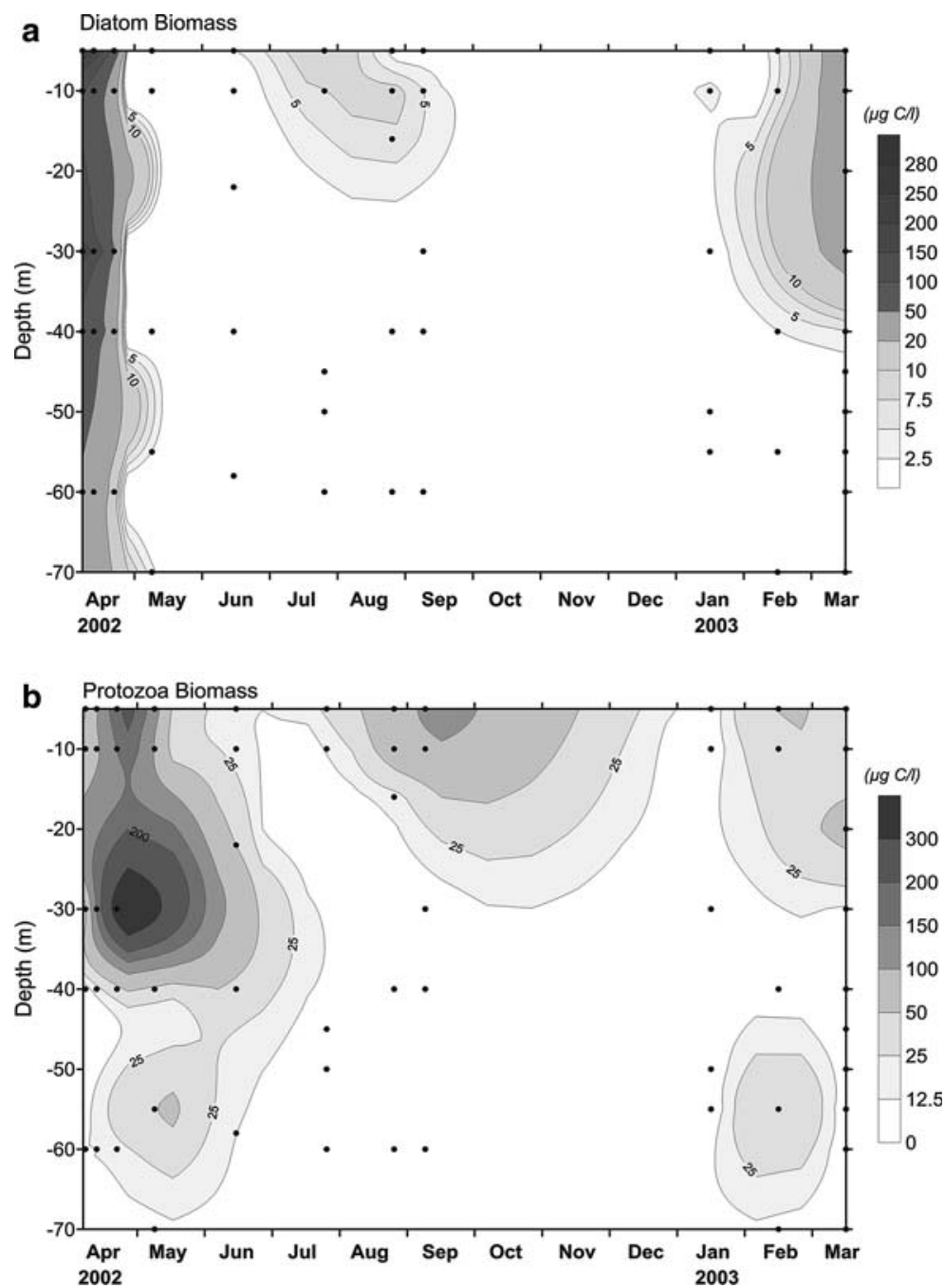

were available during the second half of April when the major Mesodinium bloom occurred.

A small Cryptophyceae maximum was identified by the Fluoroprobe near the thermocline during July and August. A near-surface Cyanophyceae maximum was recorded during summer by the Fluoroprobe with a maximum fluorescence reading corresponding to about $0.8 \mu \mathrm{g}$ chlorophyll $a 1^{-1}$. Neither of these maxima was observed using the cell count methods. This can be explained by the local character of the maxima and higher resolution of the probe in comparison to the discrete samplings for the microscopic counts.

Nutrient concentrations in the surface layer reflected the phytoplankton dynamics with highest concentrations (up to $5 \mu \mathrm{M} \mathrm{NO} 3$ and $\left.0.5 \mu \mathrm{M} \mathrm{PO}_{4}\right)$ during winter and lowest concentrations $\left(<0.01 \mu \mathrm{M} \mathrm{NO}_{3}\right.$ and $\left.0.15 \mu \mathrm{M} \mathrm{PO}_{4}\right)$ during summer (Fig. 7). During April 2002, nitrate values were already below $1 \mu \mathrm{M}$, indicating that at that time spring bloom was well under way (compare von Bodungen et al. 1981). This is in line with the high phytoplankton biomass observed at that time. Nitrate reached limiting concentrations in June/July $(<0.01 \mu \mathrm{M})$ and increased again by the end of August to reach maximum concentrations in winter. The seasonal phosphate cycle was less intense and did not reach limiting concentrations $(\sim 0.15 \mu \mathrm{M}$ in summer $)$.

The difference between the winter and late spring $\mathrm{NO}_{3}$ and $\mathrm{PO}_{4}$ concentrations $\left(\sim 4-5 \mu \mathrm{M} \mathrm{NO}\right.$ and $\sim 0.3 \mu \mathrm{M} \mathrm{PO}_{4}$ suggest that these nutrients are removed with a ratio of about 1:15 which is in good agreement with the Redfield ratio.

\section{Discussion}

In this study we present data on the seasonal and vertical distribution of nutrients, primary producers and protozooplankton in the central Baltic Sea. We combined classical methods with a novel tool, the Fluoroprobe. This enabled us to give information on the phytoplankton composition and at the same time to describe the total phytoplankton distribution at a high spatial (vertical) resolution. 
Table 1 Dominant phytoplankton and protozooplankton in the upper $10 \mathrm{~m}$ in the central Bornholm basin (Station 23)

\begin{tabular}{|c|c|c|c|c|c|c|c|}
\hline $\begin{array}{l}\text { Depth } \\
\text { (m) }\end{array}$ & Date & $\begin{array}{l}\text { Dominant } \\
\text { diatom }\end{array}$ & $\begin{array}{l}\text { Biomass } \\
(\mu \mathrm{g} / \mathrm{l})\end{array}$ & Dominant other $(\mu \mathrm{g} / \mathrm{l})$ & $\begin{array}{l}\text { Biomas } \\
(\mu \mathrm{g} / \mathrm{l}) \mathrm{s}\end{array}$ & $\begin{array}{l}\text { Dominant } \\
\text { Protozooplankton }\end{array}$ & $\begin{array}{l}\text { Biomass } \\
(\mu \mathrm{g} / \mathrm{l})\end{array}$ \\
\hline \multirow[t]{2}{*}{10} & \multirow[t]{2}{*}{15.03 .2002} & \multirow[t]{2}{*}{ Skeletonema sp. } & \multirow[t]{2}{*}{1.9} & dinophyceae athekate & 3.9 & Mesodinium rubrum & 40.5 \\
\hline & & & & Teleaulax & 1.8 & Strombidium sp. & 25.8 \\
\hline 5 & 07.04 .2002 & Skeletonema sp. & 266 & Peridiniella catenata & 6.9 & Mesodinium rubrum & 16.6 \\
\hline 10 & 07.04 .2002 & Skeletonema sp. & 97 & Peridiniella catenata & 11.3 & Mesodinium rubrum & 34.0 \\
\hline \multirow[t]{2}{*}{5} & \multirow[t]{2}{*}{08.04 .2002} & \multirow[t]{2}{*}{ Skeletonema sp. } & \multirow[t]{2}{*}{146} & Microcystis aeruginosa & 133 & Mesodinium rubrum & 28.7 \\
\hline & & & & Protoperidinium bipes & 5.6 & Favella sp. & 20.2 \\
\hline 10 & 08.04 .2002 & Skeletonema sp. & 192 & Peridiniella catenata & 11.8 & Mesodinium rubrum & 50.5 \\
\hline 5 & 11.04 .2002 & Skeletonema sp. & 24.5 & Peridiniella catenata & 18.3 & Mesodinium rubrum & 13.0 \\
\hline 10 & 11.04 .2002 & Skeletonema sp. & 97.0 & Peridiniella catenata & 20.8 & Mesodinium rubrum & 28.2 \\
\hline \multirow[t]{2}{*}{5} & \multirow[t]{2}{*}{12.04 .2002} & \multirow[t]{2}{*}{ Skeletonema sp. } & \multirow[t]{2}{*}{35.4} & Peridiniella catenata & 49.9 & \multirow[t]{2}{*}{ Mesodinium rubrum } & \multirow[t]{2}{*}{82.7} \\
\hline & & & & dinophyceae athekate & 51.6 & & \\
\hline 10 & 12.04 .2002 & Skeletonema sp. & 27.0 & Peridiniella catenata & 27.1 & Mesodinium rubrum & 83.6 \\
\hline \multirow[t]{2}{*}{5} & \multirow[t]{2}{*}{13.04 .2002} & \multirow[t]{2}{*}{ Skeletonema sp. } & \multirow[t]{2}{*}{28.7} & Peridiniella catenata & 13.2 & \multirow[t]{2}{*}{ Mesodinium rubrum } & \multirow[t]{2}{*}{76.4} \\
\hline & & & & Gymnodinium sp. & 15.9 & & \\
\hline 10 & 13.04 .2002 & Skeletonema sp. & 60.1 & Peridiniella catenata & 28.2 & Mesodinium rubrum & 45.3 \\
\hline \multirow[t]{2}{*}{5} & \multirow[t]{2}{*}{21.04 .2002} & \multirow[t]{2}{*}{ Skeletonema sp. } & 7.4 & Peridiniella catenata & 22.6 & Mesodinium rubrum & 284 \\
\hline & & & & dinophyceae athekate & 78.8 & & \\
\hline 10 & 21.04 .2002 & Skeletonema sp. & 7.8 & Peridiniella catenata & 33.6 & Mesodinium rubrum & 202 \\
\hline & & & & dinophyceae athekate & 32.9 & & \\
\hline 5 & 08.05 .2002 & Skeletonema sp. & $<0.1$ & dinophyceae athekate & 11.4 & Mesodinium rubrum & 62.8 \\
\hline & & & & Gymnodinium sp. & 5.7 & Strobilidium sp. & 6.9 \\
\hline 10 & 08.05 .2002 & & & Peridiniella catenata & 2.2 & Mesodinium rubrum & 38.6 \\
\hline & & & & dinophyceae athekate & 6.2 & Strobilidium sp. & 4.0 \\
\hline 5 & 04.06 .2002 & none & $<0.1$ & Microcystis aeruginosa & 6.9 & Mesodinium rubra & 10.4 \\
\hline & & & & Aphanizomenon sp. ${ }^{\mathrm{b}}$ & 4.6 & & \\
\hline & & & & Small nanoflagellates & 12.0 & & \\
\hline 10 & 04.06 .2002 & centrales $^{\mathrm{a}}$ & 0.9 & Microcystis aeruginosa & 21.5 & Mesodinium rubrum & 19.5 \\
\hline & & & & Aphanizomenon sp. & 5.8 & & \\
\hline & & & & Small nanoflagellates & 12.0 & & \\
\hline 5 & 25.07 .2002 & centrales $^{\mathrm{a}}$ & 7.5 & Aphanizomenon sp. & 51.2 & Mesodinium rubrum & 18.9 \\
\hline & & & & Small nanoflagellates & 14.0 & Strombidium sp. & 4.4 \\
\hline 10 & 25.07 .2002 & centrales $^{\mathrm{a}}$ & 2.8 & Cyanodictyon planctonicum & 4.5 & Mesodinium rubrum & 2.8 \\
\hline & & & & Small nanoflagellates & 11.8 & & \\
\hline 5 & 28.08 .2002 & Chaetoceros impressus & 0.1 & Small nanoflagellates & 10.2 & Helicostomella subulata & 66.9 \\
\hline & & & & Aphanizomenon sp. & 4.4 & Strobilidium sp. & 8.1 \\
\hline 10 & 28.08 .2002 & Baccilariales & 9.3 & Aphanizomenon sp. & 4.2 & Helicostomella subulata & 61.7 \\
\hline & & & & Small nanoflagellates & 4.9 & Mesodinium rubrum & 9.3 \\
\hline 5 & 07.09 .2002 & Chaetoceros danicus & 0.3 & Small nanoflagellates & 47.9 & Helicostomella subulata & 95.3 \\
\hline & & & & Dinophyceae, thecate & 9.11 & Mesodinium rubrum & 33.4 \\
\hline & & & & Dinophyceae, athecate & 14.2 & & \\
\hline 10 & 07.09 .2002 & Biddulphiales & 3.5 & Aphanizomenon sp. & 5.3 & Helicostomella subulata & 82.7 \\
\hline & & & & Small nanoflagellates & 7.3 & Mesodinium rubrum & 7.1 \\
\hline 5 & 16.11 .2002 & Biddulphiales & 0.9 & Cryptophyceae & 0.6 & Mesodinium rubrum & 1.7 \\
\hline & & & & Dinophyceae, thecate & 0.3 & Strombidium sp. & 2.8 \\
\hline
\end{tabular}

a centrales: this species was originally recorded as Podosira stelliger. This is most probably a misidentification, as this species has not been previously observed in this part of the Baltic (Hällfors 2004)

b Recent investigations (Laamanen et al. 2002) suggest that Aphanizomenon sp. is genetically identical with A. flos-aqua 
Fig. 4 Mean Biomass of a diatoms (Bacillariophyceae) and dinoflagellates (Dinoflagellates: filled) and $\mathbf{b}$ protozooplankton (Mesodinium rubrum: filled) in the upper $10 \mathrm{~m}$ of the Bornholm Basin (Station 23). The dominant species and their biomass are presented in Table 1)
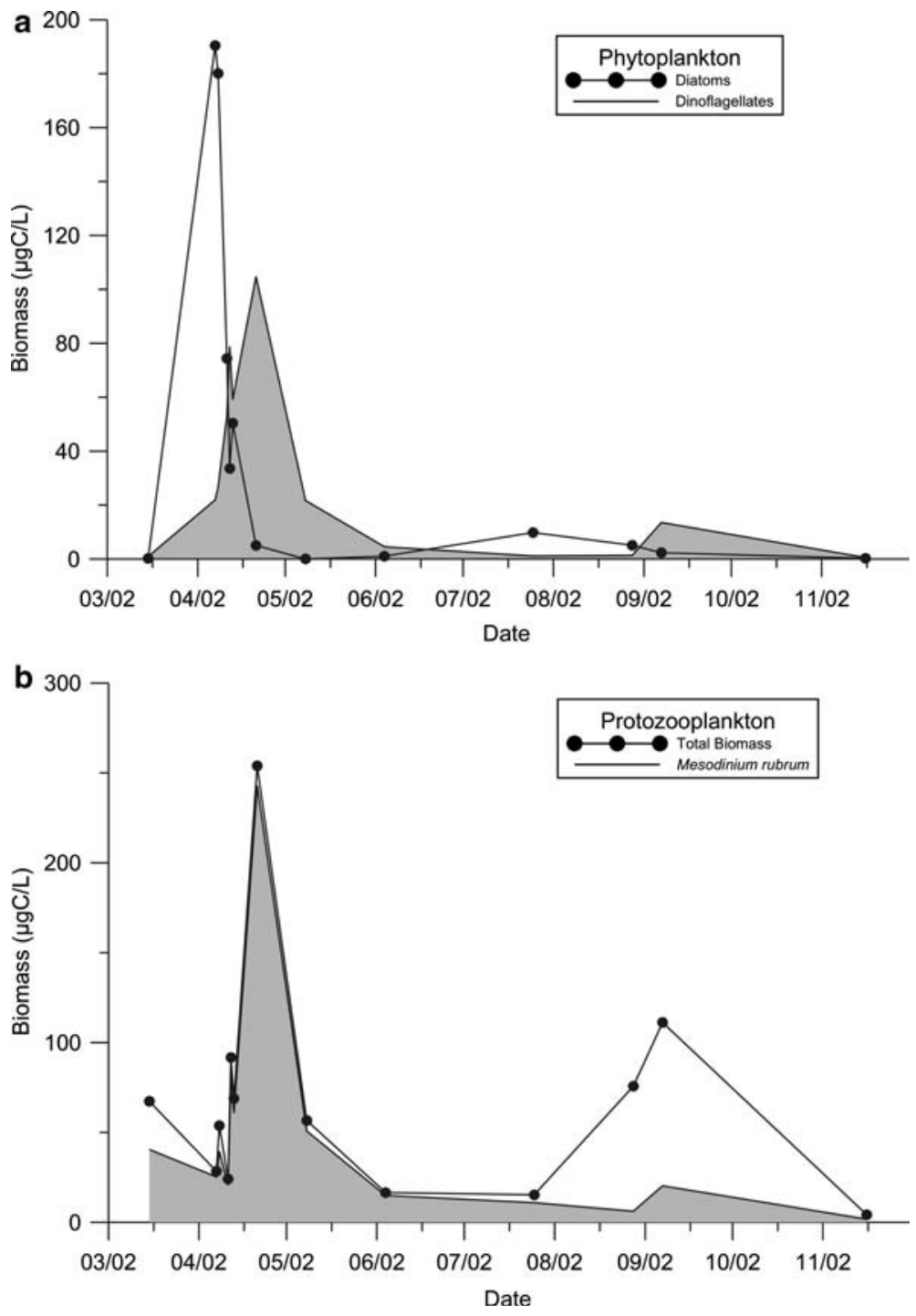

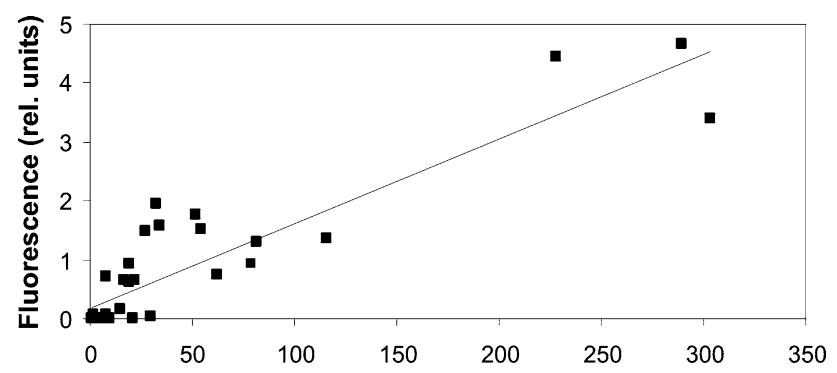

Fig. 5 Correlation between fluorescence (relative units, about equal to $1 \mu \mathrm{g}$ chlorophyll $a 1^{-1}$ ) and total phytoplankton biomass $\left(\mu \mathrm{g} \mathrm{C}^{-1}\right)$. Best fit: $y=0.0144 x+0.178 ; R^{2}=0.816$

The Fluoroprobe is a useful instrument to measure phytoplankton distribution with a high spatial resolution (Beutler et al. 2001, 2002, this study), and a penetration depth much higher than with satellite imaging. The biomass estimates are in reasonable agreement with the biomass estimates based on cell counts. The advantage of

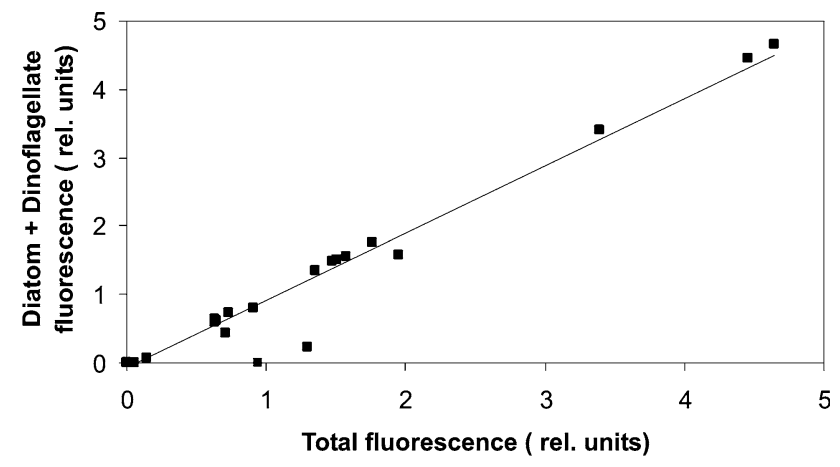

Fig. 6 Correlation between diatom + dinoflagellate fluorescence as measured by the Fluoroprobe with the total fluorescence for all samples where phytoplankton was enumerated $(y=0.98 x-0.075$; $\left.R^{2}=0.96\right)$

the instrument is its ability to distinguish between different algal groups on the basis of their fluorescence characteristics. Small-scale features like the surface layer of 
Fig. 7 Seasonal dynamics of nitrate $\left(\mu \mathrm{mol} 1^{-1}\right.$, top panel $)$ and phosphate $\left(\mu \mathrm{mol} 1^{-1}\right.$, bottom panel) in the upper $70 \mathrm{~m}$ at Station 23. Black markers indicate measurements
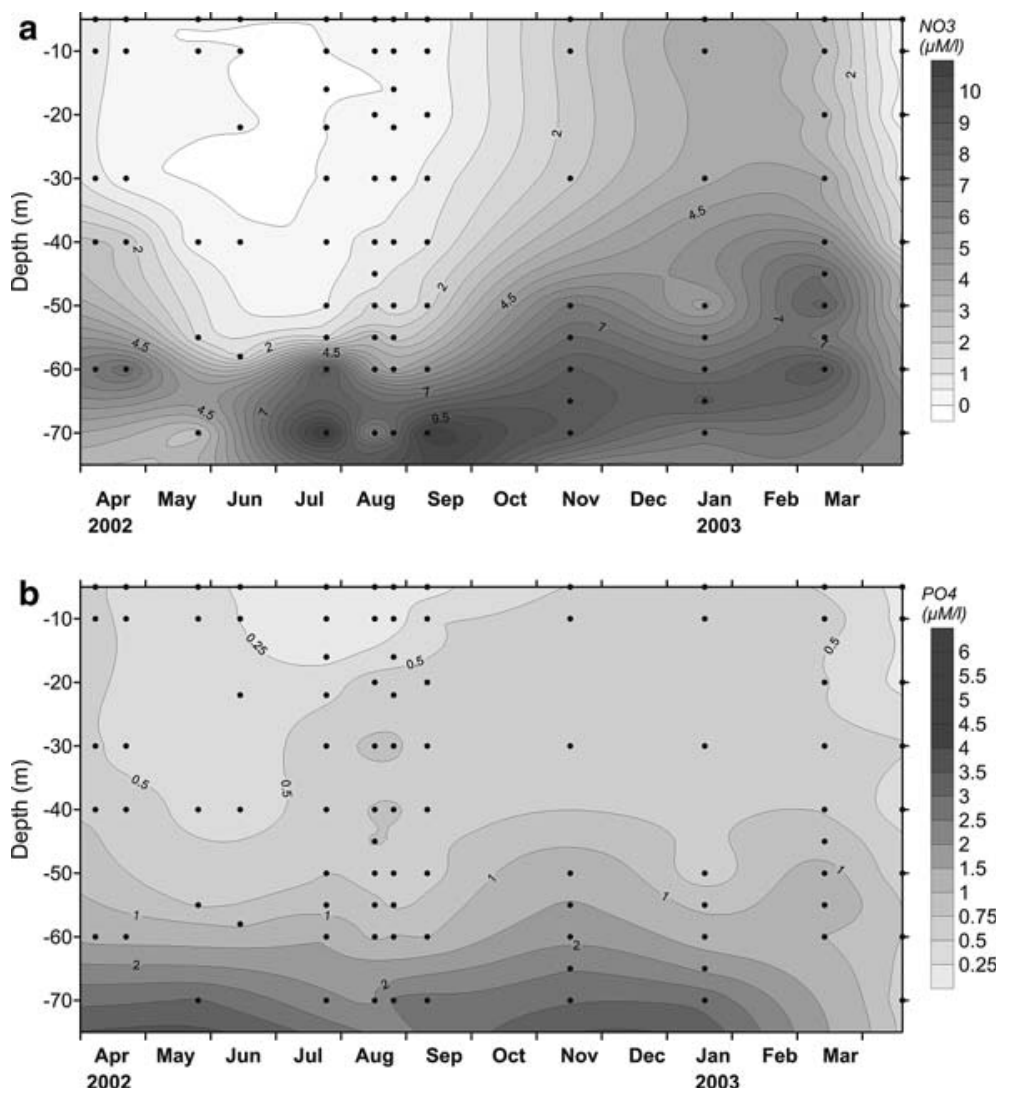

Cyanophyceae and the small Cryptophyceae maximum at the base of the thermocline could not be reproduced by microscopic observations, most likely because these layers were not adequately sampled. Obviously, the main draw back of the Fluoroprobe is that it only measures in large groups based on fluorescence characteristics, not being able to deal with higher taxonomic resolution. This is especially important in the present situation where the major protozoan species was Mesodinium rubrum. This protozoan is capable of photosynthesis due to cryptophycean endosymbionts (e.g., Crawford 1989) implying that this protozoan should be included in the autotrophic compartment and that its presence might mimic the presence of Cryptophyceans. We found no relation between Mesodinium biomass and fluorescence However, this still leaves the question open, whether the cryptophyceae maxima observed during summer in the thermocline was due to free living cryptophyceans or endosymbionts of Mesodinium. No water samples were available to directly check both possibilities by microscopy. Three aspects however suggest that we were dealing with free-living cryptophyceae in the thermocline. First of all, Mesodinium biomass always showed highest concentrations in the upper few meters (e.g., Table 1). Secondly, Mesodinium was found in relatively low concentration during the period of the cryptophyceae maximum. Thirdly, no correlation was found between Mesodinium biomass and the fluorescence attributed to cryptophyceae. A further draw back of the Fluoroprobe is the fact that it only observes fluorescent plankton components. We therefore conclude that, unfortunately, we will not be able to only use only one instrument to obtain a proper picture of the plankton dynamics in temperate seas. Even though the Fluoroprobe proved to be highly versatile and gave good correlations between the total carbon content of the phytoplankton based on counts, the distinction of the different algal groups remains troublesome. This is most likely caused by the rather low total chlorophyll concentrations and due to the fact that dinoflagellates and diatoms dominated the autotrophic phytoplankton compartment. Furthermore, we found that protozooplankton can attain high biomasses at certain times of the year. At least the non-fluorescent species are invisible for the probe. Hence, a combined approach of deploying the Fluoroprobe to give a highresolution distribution pattern of phytoplankton biomass and to find "areas" of interest followed by subsequent sampling are the strategy of choice.

Our data clearly show that the diatom spring bloom started before the onset of the stratification reaching a maximum biomass of about 250-300 $\mu \mathrm{g} \mathrm{C}$ and a fluorescence reading equal to about $5 \mu \mathrm{g}$ chlorophyll $a$. The bloom was dominated by the diatom Skeletonema sp. It has 
been discussed whether these blooms are triggered locally, or if they are advected from shallower coastal regions (Wasmund et al. 1998). With our data we cannot answer this question. However, the data show that the spring population was actively growing as nutrients and especially nitrate was rapidly consumed over the upper $30 \mathrm{~m}$ (Fig. 7). Also in March 2003, nitrate concentrations started to decrease in the upper $30 \mathrm{~m}$ before stratification (Fig. 7) suggesting that good growth conditions prevailed. Von Bodungen et al. (1981) also concluded that the spring bloom in the Bornholm Basin started before the onset of stratification. In their case, advection was ruled out as a factor influencing the bloom dynamics.

Long-term trends in phytoplankton development in the Baltic Sea indicate a general decrease in diatom biomass and an increase in dinoflagellate biomass (Wasmund and Uhlig 2003). Wasmund et al. (1998) described that in 1994 the spring bloom in the Bornholm Basin was dominated by dinoflagellates (Peridiniella catenata). Our results indicate a reversal of this trend as the spring bloom was clearly dominated by diatoms (Skeletonema sp.). Monitoring data support this (Wasmund et al. 2003). After this bloom a dinoflagellate bloom with $P$. catenata as one of the main species developed. The spring bloom dynamics observed during our study showed some similarities with the bloom pattern observed by von Bodungen et al. (1981) during 1975. These authors also observed a Skeletonema dominated spring bloom, however, with a somewhat lower maximum biomass (about $100 \mu \mathrm{g} \mathrm{C}^{-1}$ ). During the 1975 spring bloom also Mesodinium contributed significantly to the total biomass whereas $P$. catenata was not mentioned. The latter two observations contrast with the situation during 2002, where P. catenata and Mesodinium peaked after the diatom bloom.

Protozooplankton seems to follow the main phytoplankton bloom in spring. We found a time-lag between the occurrence of the primary producers and the main peak of the heterotrophs of about 2 weeks. During late summer (early September), protozoan biomass showed a second peak 6 weeks after a small summer bloom during late July. This large lag as compared to the spring (about 2 weeks) suggests that other processes than food availability are responsible for the second protozooplankton peak, such as a relaxation of the grazing pressure on the protozoans. Support for the latter is given by Möllmann et al. (2000). They described the seasonal abundance of copepods in the Bornholm Basin and showed that biomass decreased from August onwards. The importance of ciliates as an important food item for copepods in the Bornholm Basin was demonstrated by Peters et al. (2006).

As in the study of Maar et al. (2004) we generally observed the largest densities of the protozooplankton at the surface, but occasionally, high biomasses were observed in deeper layers. In contrast to the maximum concentrations of around $50 \mu \mathrm{g} \mathrm{C} 1^{-1}$ found by Maar et al. (2004) we found during spring and autumn higher values of 100-300 $\mu \mathrm{g} \mathrm{C}^{-1}$ reaching an occasional maximum value up to about $500 \mu \mathrm{g} \mathrm{C}^{-1}$. Maar et al. (2004) concluded that the total biomass of heterotrophs, being well below the food saturation levels of $200-500 \mu \mathrm{g} \mathrm{C} 1^{-1}$ is not high enough to meet the carbon demand of adult females. Their study was in the Skagerrak, ours in the Bornholm Basin, and the concentrations of $100-300 \mu \mathrm{g}$ $\mathrm{C}^{-1}$ could well sustain adult copepod demand during spring. During summer, heterotrophic biomass was generally low, suggesting potential food limitation for copepods but during autumn the heterotrophic biomass reached again levels close to those levels that may sustain copepod growth. Is this relevant for the development of the system, and secondary production in general? We believe it is. Based on the study of Peters et al. (2006), which was carried out parallel to our investigations, we know that there is a strong trophic signal of ciliates in Pseudocalanus acuspes (one of the dominant copepods in the Bornholm Basin). The trophic signal was measured as ciliate-specific fatty acids. Older stages of Pseudocalanus spp. are very well capable of feeding on ciliates (Klein Breteler et al. 2004), and in many cases ciliates are eaten preferentially by copepods (Sommer 2003), even though the nutritive value of these organisms for copepods is still under discussion (Broglio et al. 2003; Klein Breteler et al. 2004; Tang and Taal 2005). Since older stages of Pseudocalanus acuspes, the ones that are large enough to consume protozooplankton mainly stay in the deeper layer in the early part of the year (Peters et al. 2006) they will find abundant food at depth, consisting mainly of heterotrophic food sources. Interestingly, this is also the period when egg production is highest (Peters et al. 2006). Moreover, in the first few days of their life larval sprat feed almost exclusively on micro- and protozooplankton (Dickmann 2005), and the timing of the main protozooplankton bloom (March-April) coincides with the time that sprat are in the size class that they consume large amounts of protozooplankton.

In conclusion, phytoplankton and protozooplankton can be found in similar biomasses during different times of the year in the Bornholm Basin in the Baltic Sea. Our observation that egg production of $P$. acuspes was highest during the times of high protozooplankton abundance suggests that protozooplankton dynamics are probably one of the main drivers of secondary production in the Baltic Sea.

Acknowledgments We thank all participants of the many GLOBEC-Cruises for their help in collecting the samples. Comments by two reviewers considerably improved the manuscript. This study was funded through the GLOBEC-Germany project (03F0320C) by the German Federal Ministry of Science and Education (BMBF). 


\section{References}

Alheit J (2004) The GLOBEC-Germany Project. Int Globec Newsl $10: 9$

Augustin CB, Boersma M (2006) Effects of nutritional stress on different Acartia species. J Plankton Res 28(4):429-436

Beutler M, Wiltshire KH, Meyer B, Moldaenke C, Dau H (2001) In situ profiles of phytoplankton: algal composition and biomass determined fluorometrically. In: Ninth international conference on harmful algal blooms, Hobart (Australia), pp 202-205

Beutler M, Wiltshire $\mathrm{KH}$, Meyer $\mathrm{B}$, Moldaenke C, Luring $\mathrm{C}$, Meyerhofer M, Hansen UP Dau H (2002) A fluorometric method for the differentiation of algal populations in vivo and in situ. Photosynth Res 72:39-53

Broglio E, Jonasdottir SH, Calbet A, Jakobsen HH, Saiz E (2003) Effect of heterotrophic versus autotrophic food on feeding and reproduction of the calanoid copepod Acartia tonsa: relationship with prey fatty acid composition. Aquat Microb Ecol 31:267278

Cloern JE, Grenz C, Vidergar-Lucas L (1995) An empirical model of the phytoplankton chlorophyll:carbon ratio-the conversation factor between productivity and growth rate. Limnol Oceanogr 40:1313-1321

Crawford DW (1989) Mesodinium rubrum: the phytoplankter that wasn't. Mar Ecol Prog Ser 58:161-174

Dickmann M (2005) Feeding ecology of sprat (Sprattus sprattus L.) and sardine (Sardina pilchardus W.) larvae in the Baltic Sea and in the North Sea. PhD Thesis, University of Rostock, p 93

Edler L (1979) Recommendations on methods for marine biological studies in the Baltic Sea. Phytoplankton and chlorophyll. Baltic Mar Biol 5:1-38

Fennel W (1995) A model of the yearly cycle of nutrients and plankton in the Baltic Sea. J Mar Syst 6:313-329

Fleming V, Kaitala S (2006) Phytoplankton spring bloom intensity index for the Baltic Sea estimated for the years 1992 to 2004. Hydrobiologia 554:57-65

Gordon HR, McCuley A (1975) Estimation of the depth of sunlight penetration in the sea for remote sensing. Appl Opt 14:413-416

Gustafson DEJ, Stoecker DK, Johnson MD, Van Heukelem WF, Sneider K (2000) Cryptophyte algae are robbed of their organelles by the marine ciliate Mesodinium rubrum. Nature 405:1049-1052

Graneli E, Turner JT (2002) Top-down regulation in ctenophorecopepod-ciliate-diatom- phytoflagellate communities in coastal waters: a mesocosm study. Mar Ecol Prog Ser 239:57-68

Hällfors G (2004) Checklist of Baltic Sea phytoplankton species: including some heterotrophic protistan groups. Baltic Sea environment proceedings. Baltic Environmental Protection Commission-HELCOM, p 95

Hinrichsen HH, Lehmann A, Möllmann C, Schmidt JO (2003) Dependency of larval fish survival on retention/dispersion in food limited environments: the Baltic Sea as a case study. Fish Oceanogr 12:425-433

Hirche HJ, Meyer U, Niehoff B (1997) Egg production of Calanus finmarchicus: Effect of temperature, food and season. Mar Biol 127:609-620

Johansson M, Gorokhova E, Larsson U (2004) Annual variability in ciliate community structure, potential prey and predators in the open northern Baltic Sea proper. J Plankton Res 26:67-80

Kivi K (1993) Nutrient limitation and grazing control of the Baltic plankton community during annual succession. Limnol Oceanogr 38:893-905

Klein Breteler WCM., Koski M, Rampen S (2004) Role of essential lipids in copepod nutrition: no evidence for trophic upgrading of food quality by a marine ciliate. Mar Ecol Prog Ser 274:199-208
Laamanen MJ, Forsström L, Sivonen K (2002) Diversity of Aphanizomenon populations (cyanobacteria) on a Baltic Sea salinity gradient-only one ITS1-S genotype persits in the Baltic Sea. In: Laamanen MJ (ed) Genetic and species diversity of planktonic cyanobacteria in the northern Baltic Sea. Contributions of the Finnish Inst. of Marine Research, Helsinki, vol. 4, Part IV, p 14

Maar M, Nielsen TG, Gooding S, Tonnesson K, Tiselius P, Zervoudaki S, Christou E, Sell A, Richardson K (2004) Trophodynamic function of copepods, appendicularians and protozooplankton in the late summer zooplankton community in the Skagerrak. Mar Biol 144:917-933

Maar M, Nielsen TG, Richardson K, Christaki U, Hansen OS, Zervoudaki S, Christou E (2002) Spatial and temporal variability of food web structure during the spring bloom in the Skagerrak. Mar Ecol Prog Ser 239:11-29

Malzahn AM (2006) Larval fish dynamics in changing environments. $\mathrm{PhD}$ Thesis, University of Kiel, p 98

Möllmann C, Kornilovs G, Sidrevics L (2000) Long-term dynamics of main mesozooplankton species in the central Baltic Sea. J Plankton Res 22:2015-2038

Peters J, Renz J, van Beusekom JEE, Boersma M, Hagen W (2006) Trophodynamics and seasonal cycle of the copepod Pseudocalanus acuspes in the Central Baltic Sea (Bornholm Basin) evidence from lipid composition. Mar Biol 149:1417-1429

Platt T, Sathyendranath S (1988) Oceanic primary production: estimation by remote sensing at local and regional scales. Science 241:1561-1724

Putt D, Stoecker DK (1989) An experimentally determined carbon: volume ratio for marine "oligotrichous" ciliates from estuarine and coastal waters. Limnol Oceanogr 34:1097-1103

Renz J, Hirche HJ (2006) Life cycle of Pseudocalanus acuspes Giesbrecht (Copepoda, Calanoida) in the Central Baltic Sea: I. Seasonal and spatial distribution. Mar Biol 148:567-580

Setala O, Kivi K (2003) Planktonic ciliates in the Baltic Sea in summer: distribution, species association and estimated grazing impact. Aquat Microb Ecol 32:287-297

Sommer F (2003) A comparison of the impact of major mesozooplankton taxa on marine, brackish and freshwater phytoplankton during summer. PhD Thesis, University of Kiel, Berichte aus dem Institut für Meereskunde an der Universität Kiel, No. 329, p 91

St John MA, Clemmesen C, Lund T, Köster F (2001) Diatom production in the marine environment: implications for larval fish growth and condition. ICES J Mar Sci 58:1106-1113

Tang KW, Taal M (2005) Trophic modification of food quality by heterotrophic protists: species-specific effects on copepod egg production and egg hatching. J Exp Mar Biol Ecol 318:85-98

Utermöhl H (1958) Zur Vervollkommnung der quantitativen Phytoplanktonmethodik. Mitt Int Verh Theor Angew Limnol 9:1-38

von Bodungen B, von Bröckel K, Smetacek V, Zeitschel B (1981) Growth and sedimentation of the phytoplankton spring bloom in the Bornholm Basin. Kieler Meeresforschung Sonderheft 5:4960

Wasmund N, Nausch G, Mathäus W (1998) Phytoplankton spring blooms in the southern Baltic Sea-spatio-temporal development and long-term trends. J Plankton Res 20:1099-1117

Wasmund N, Pollehne F, Postel L, Siegel H, Zettler ML (2003) Assessment of the biological state of the Baltic Sea in 2002 (in German). Meereswiss Ber 56:1-78

Wasmund N, Uhlig S (2003) Phytoplankton trends in the Baltic Sea. ICES J Mar Sci 60:177-186 